\title{
FAKTOR YANG MEMPENGARUHI KEIKUTSERTAAN SENAM LANSIA DI WILAYAH KERJA PUSKESMAS TITUE
}

Factors That Influence The Elderly Gymnastics Participants In Titue Health Center

\author{
Karmila ${ }^{1}$, Kartika ${ }^{2}$, Arnita $^{3}$ \\ 1 STIKes Medika Seramoe Barat \\ ,2,3 STIKes Medika Nurul Islam \\ Email : milabahridr@gmail.com
}

\begin{abstract}
The success of the government in National Development, can be said to be successfully proven by the increase in life expectancy, which means that also increases the elderly population. Health improvement for the elderly, one of which can be done with regular exercise or gymnastics, but in fact there are still many elderly people who do not take part in elderly exercise. The purpose of this study was to find out the factors that influence the participation of elderly gymnastics in the Titeue Community Health Center work area. The type of research used in this study is analytical with a crosssectional approach. The research was conducted in the working area of the Titue Health Center. This research sample is 107 people. Data analysis used is multiple logistic regression test. The results showed that there were effects of age $(p=0.007)$, physical $(p=0,000)$ and motivation $(p=0.019)$ on the participation of elderly gymnastics in the Titue Health Center Working Area. It is expected that the Titeue Community Health Center is expected to further optimize the health services of the elderly, especially elderly gymnastics by providing motivations involving elderly peers.

Keywords: Elderly Gymnastics, age, physical condition, motivation
\end{abstract}

\begin{abstract}
Abstrak
Keberhasilan pemerintah dalam Pembangunan Nasional, bisa dikatakan berhasil dibuktikan dengan adanya peningkatan umur harapan hidup, yang berarti bertambah pula populasi lanjut usia. Peningkatan kesehatan pada lansia yang salah satunya dapat dilakukan dengan olahraga atau senam secara teratur, tetapi pada kenyataanya masih banyak lansia yang tidak mengikuti senam lansia. Tujuan dalam penelitian ini adalah Mengetahui faktor-faktor yang mempengaruhi keikutrsertaan senam lansia di wilayah kerja Puskesmas Titeue. Jenis penelitian yang digunakan dalam penelitian ini adalah analitik dengan pendekatan cross sectional. Penelitian dilaksanakan di wilayah kerja Puskesmas Titue. Sample penalitian ini sebanyak 107 orang. Analisis data yang digunakan adalah uji regresi logistik berganda. Hasil penelitian menunjukkan bahwa terdapat pengaruh umur $(p=0,007)$, fisik $(p=0,000)$ dan motivasi $(p=0,019)$ terhadap keikutsertaan senam lansia di Wilayah Kerja Puskesmas Titue. Diharapkan kepada Puskesmas Titeue diharapkan dapat lebih mengoptimalkan pelayanan kesehatan lansia terutama senam lansia dengan memberikan motivasi-motivasi yang melibatkan teman sebaya lansia.
\end{abstract}

Kata Kunci : Senam Lansia, umur, kondisi fisik, motivasi 


\section{PENDAHULUAN}

Pembangunan Nasional dapat dikatakan berhasil dan mewujudkan hasil yang positif di berbagai bidang. Keberhasilan tersebut dapat dilihat dengan adanya kemajuan ekonomi, ilmu pengetahuan dan teknologi, terutama dalam bidang medis, ilmu kedokteran dan keperawatan. Indokator keberhasilan salah satunya dengan peningkatan umur harapan hidup, yang berarti bertambah pula populasi lanjut usia (lansia) (Widyastuti, 2013).

Sejak tahun 2000, penduduk lansia Amerika yang berusia 65 tahun ke atas telah bertambah dua kali lipat, dan penduduk lansia yang lemah berusia 85 tahun ke atas telah bertambah lebih dari empat kali lipat. Tahun 2010 penduduk usia lanjut di seluruh dunia sebanyak 589 juta, jumlah ini akan terus meningkat hampir dua kali lipat pada tahun 2025 yaitu sekitar 828 juta jiwa (WHO, 2010).

Menurut Martono dan Pranarka, (2009) di negara-negara maju, jumlah lansia ternyata juga mengalami peningkatan, antara lain: Kenya $347 \%$, Brazil 255\%, India 242\%, China 220\%, Jepang 129\%, Jerman 66\% dan Swedia 33\%. Berdasarkan data statistik, jumlah lansia di Indonesia pada tahun 2015 berjumlah 25 juta jiwa dan diperkirakan akan terus meningkat setiap tahunnya (PPKS Aceh, 2016).

Tanda-tanda masa tua disertai dengan adanya kemunduran-kemunduran kemampuan kerja panca indra, gangguan fungsi alat-alat tubuh, perubahan psikologi serta adanya berbagai penyakit yang muncul. Upaya yang dapat dilakukan dengan cara peningkatan kesehatan pada lansia yang salah satunya dapat dilakukan dengan olahraga atau senam secara teratur (Ekasari, 2008).

Senam lansia merupakan bentuk peran serta masyarakat untuk mencapai derajat kesehatan yang optimal serta kondisi menua yang sehat dan mandiri. Senam lansia adalah berbagai gerak nada yang teratur dan terarah serta terencana yang dilakukan untuk meningkatkan kemampuan fungsional raga untuk mencapai tujuan tersebut. Manfaatnya adalah membantu tubuh tetap sehat, bugar dan segar dan membantu menghilangkan radikal bebas yang ada di dalam tubuh (Agustina, 2010).
Jenis olahraga yang dapat dipilih lansia sebagai aktivitas fisik adalah senam. Melakukan olahraga secara teratur dapat memperlambat atau mencegah hilangnya fungsi organ. Beberapa penelitian menunjukkan bahwa senam pada lansia bisa mengurangi berbagai macam resiko (Moniaga, 2013).

Sharkey (2013) menyatakan bahwa kegiatan latihan fisik dan olahraga secara teratur dengan dosis yang tepat selain bermanfaat secara fisiologik meningkatkan masa otot, membantu mempertahankan elestisitas pembuluh darah,dan tekanan darah serta mengurangi kerja jantung, meningkatkan difusi oksigen dari paru-paru ke dalam darah serta mempertahankan fungsi hormonal dan reproduksi. Sedangkan menurut Pujiastuti (2013) kegiatan latihan fisik juga dapat menjangkau aspek mental diantaranya lebih percaya diri, gembira, merasa segar, lebih kreatif, menurunkan stress dan ketegangan, menjadi lebih ramah dan meningkatkan spontanitas. Dengan demikian kegiatan latihan fisik sudah menjadi kebutuhan untuk tujuan peningkatan status kesehatan dan kebugaran jasmani seseorang.

Hasil penelitian Budiharjo (2009) mengatakan bahwa partisipasi lansia untuk melakukan senam kurang memuaskan, faktor penyebab kurangnya partisipasi adalah kurangnya pengetahuan tentang senam lansia. Hasil penelitian ini sejalan dengan penelitian yang dilakukan oleh Dhenok (2008) yaitu pengetahuan lansia yang baik tentang latihan fisik dapat meningkatkan kegiatan senam. Hal ini bisa saja disebabkan karena rendahnya kesadaran lansia dan pengetahuan akan pentingnya mengikuti kegiatan senam.

Kelompok usia lanjut sebagai suatu bentuk pemberdayaan masyarakat, sangat tergantung dari peran masyarakat atau kelompok usi lanjut itu sendiri. Dalam pelaksanaanya peran petugas kesehatan atau petugas lain dalam pembinaan, agar kelangsungan dan kesinambungan kegiatan senam lansia tetap berjalan dan terpelihara.

Survey awal yang peneliti lakukan di Puskesmas Titeue Kecamatan Titeue Kabupaten Pidie didapatkan data bahwa pelaksanaan kegiatan 
senam lansia dilaksanakan rutin setiap hari rabu sejak tanggal 30 Oktober 2013. Secara umum, upaya pelaksanaan kegiatan tersebut oleh puskesmas sudah sangat bagus dimana mereka menyediakan sarana pendukung seperti tape / radio dan pelaksanaan kegiatannya juga dibimbing oleh instruktur sehingga gerakan senam lebih teratur. Berdasarkan data dari Puskesmas Titeue wilayah kerja Puskesmas Titeue terdiri dari 13 desa dan jumlah lansia sebanyak 376 lansia dan hanya sedikit yang mengikuti senam.

\section{BAHAN DAN METODE}

Jenis penelitian yang digunakan dalam penelitian ini adalah analitik dengan pendekatan crosssectional, yaitu cara pendekatan, observasi atau pengumpulan data sekaligus pada suatu saat, dimana pengumpulan data dilakukan disaat yang bersamaan untuk menentukan faktor yang mempengaruhi keikutsertaan senam lansia. Populasi adalah keseluruhan lansia yang berada di wilayah kerja Puskesmas Titue sebanyak 376. Sample penalitian ini sebanyak 107 orang. Tehnik pengambilan sampel dengan cara simple random sampling. instrumen yang digunakan dalam penelitian ini adalah berupa kuesioner Analisis data yang digunakan adalah uji regresi logistik berganda.

\section{HASIL DAN PEMBAHASAN}

\section{Analisis Univariat}

Hasil analisis deskriptif dalam penelitian ini terdiri dari umur, kondisi fisik, motivasi, informasi dan keikutsertaan senam dapat dilihat pada tabel 1 .

Hasil penelitian menunjukkan bahwa mayoritas lansia berumur 49-54 Tahun sebanyak 55 orang $(51,4 \%)$, pada variabel kondisi fisik mayoritas kurang sebayak 59 orang (52,0\%). Motivasi lansia mayoritas ada motivasi sebanyak 62 orang $(57,9 \%)$. Informasi mayoritas menyatakan responden tidak mendapatkan informasi sebanyak 59 orang yaitu sebanyak orang $(62,0 \%)$ dan keikutsertaan senam lansia mayoritas tidak mengikuti senam lansia sebanyak 66 orang $(61,7 \%)$.
Tabel 1. Distribusi Frekuensi Berdasarkan Pendidikan, Pengetahuan, Sikap, Motivasi, dan Peran Kader di Wilayah Kerja Puskesmas Mila Kabupaten Pidie

\begin{tabular}{lcc}
\hline Vaiabel & $\mathbf{n}$ & $\mathbf{\%}$ \\
\hline Umur & & \\
$\geq 55$ Tahun & 52 & 48.6 \\
49-54 Tahun & 55 & 51.4 \\
\hline Kondisi Fisik & & \\
Kurang & 59 & 55,1 \\
Baik & 48 & 44,9 \\
\hline Motivasi & & \\
Tidak ada & 45 & 42,1 \\
Ada & 62 & 57,9 \\
\hline Informasi & & \\
Tidak ada & 59 & 55,1 \\
Ada & 48 & 44,9 \\
\hline Keikutsertaan Senam Lansia & & \\
Tidak & 66 & 61,7 \\
Ya & 41 & 38,3 \\
\hline
\end{tabular}

\section{Analisis Bivariat}

Analisis hubungan antara umur, kondisi fisik, motivasi, informasi dengan keikutsertaan senam lansia dapat dilihat pada tabel 2.

Analisis hubungan antara umur lansia didapatkan nilai $\mathrm{p}=0,027<0,05$ yang berarti ada hubungan usia dengan keikutsertaan senam lansia di Wilayah Kerja Puskesmas Titue. Terdapat hubungan kondisi fisik $(p=0,000)$ dan motivasi $(p=0,004)$ dengan keikutsertaan senam lansia di Wilayah Kerja Puskesmas Titue dan tidak ada hubungan informasi $\mathrm{p}=0,149>0,05$ dengan keikutsertaan senam lansia di Wilayah Kerja Puskesmas Titue.

Green menyatakan perilaku manusia yang terwujud dalam bentuk keaktifannya untuk datang ke posyandu lansia ini merupakan refleksi dari berbagai gejala kejiwaan seperti pengetahuan, keinginan, kehendak, minat, motivasi, persepsi, sikap dan sebagainya (Mamik, 2013). 
Tabel 2. Faktor Yang Berhubungan Dengan Keikutsertaan Senam Lansia di Wilayah Kerja Puskesmas Titue

\begin{tabular}{|c|c|c|c|c|c|c|c|}
\hline \multirow{3}{*}{ Variabel } & \multicolumn{4}{|c|}{ Keikutsertaan Senam } & \multirow{2}{*}{\multicolumn{2}{|c|}{ Jumlah }} & \multirow{3}{*}{ Sig. } \\
\hline & \multicolumn{2}{|c|}{ Tidak Aktif } & \multicolumn{2}{|c|}{ Aktif } & & & \\
\hline & $\mathrm{f}$ & $\%$ & $\mathrm{f}$ & $\%$ & $f$ & $\%$ & \\
\hline \multicolumn{8}{|l|}{ Umur } \\
\hline$\geq 55$ Tahun & 37 & 72,5 & 14 & 27,5 & 51 & 100,0 & 0,027 \\
\hline 49-55 tahun & 29 & 51,8 & 27 & 48,2 & 56 & 100,0 & \\
\hline \multicolumn{8}{|l|}{ Kondisi Fisik } \\
\hline Kurang & 49 & 83,1 & 10 & 16,9 & 59 & 100,0 & 0,000 \\
\hline Baik & 17 & 35,4 & 31 & 64,6 & 48 & 100,0 & \\
\hline \multicolumn{8}{|l|}{ Motivasi } \\
\hline Tidak ada & 35 & 77,8 & 10 & 22,2 & 45 & 100,0 & 0,004 \\
\hline Ada & 31 & 50,0 & 31 & 50,0 & 62 & 100,0 & \\
\hline \multicolumn{8}{|l|}{ Informasi } \\
\hline Tidak ada & 40 & 67,8 & 19 & 32,2 & 31 & 100,0 & 0,149 \\
\hline Ada & 26 & 54,2 & 22 & 45,8 & 19 & 100,0 & \\
\hline
\end{tabular}

Tabel 3. Faktor Yang Mempengaruhi Keikutsertaan Senam Lamsia di wilayah Kerja Puskesmas Titue

\begin{tabular}{llll}
\hline Variabel & B & Sig. & Exp(B) \\
\hline Umur & 1.477 & 0,007 & 4,378 \\
Fisik & 2,339 & 0,000 & 10,375 \\
Motivasi & 1,279 & 0,019 & 3,595 \\
Constant & $-3,331$ & & \\
\hline
\end{tabular}

Hasil penelitian menunjukkan bahwa terdapat pengaruh umur terhadap keikutsertaan senam lansia di Wilayah Kerja Puskesmas Titue. Umur merupakan salah satu penentu keaktifan lansia dalam beraktifitas, semakin tua umur lansia maka semakin terbatas juga aktifitas yang dilakukan. Dalam penelitian umur l;ansia yang paling banyak mengikuti senam lansia adalah lansia yang berusia 49-55 tahun dibandingkan lansia yang berusia 56 tahun keatas.

Hasil penelitian ini sesuai dengan penelitian yang dilakukan oleh Sulastri (2006) menemukan bahwa di wilayah kerja Puskesmas Medan Deli ditemukan bahwa variabel umur lansia juga berpengaruh signifikan terhadap minat lansia untuk melakukan senam lansia dengan nilai $p=0,001$. Dalam penelitian tersebut diketahui bahwa data demografi yang didapatkan hasil yang paling banyak melakukan senam lansia berada pada umur 60-74 tahun (usia lanjut) dan memiliki motivasi yang rendah terhadap aktivitas senam lansia, sehingga
Sulastri beranggapan banyaknya lansia yang tidak mengikuti senam lansia karena faktor umur yang semakin tua dan menyebabkan keterbatasan dan penurunan aktivitas fisik.

Penelitian yang dilakukan oleh Ninggrum (2008) di wilayah kerja Puskesmas Banyudono Jawa Tengah bahwa juga menyatakan bahwa umur lansia berpengaruh secara signifikan terhadap motivasi lansia dalam melakukan senam lansia dengan nilai $p=0,003$.

Berdasarkan lansia yang mengikuti senam lansia mayoritas berada pada kategori umur middle age (45 - 59 tahun) sehingga bisa dilihat bahwa usia masa awal usia lanjut memiliki kondisi fisik yang lebih baik dibandingkan lansia pada kategori umur lebih dari 59 tahun dimana semakin tua seseorang maka akan semakin memiliki keterbatasan dan penurunan aktivitas fisik. Pada usia middle age lansia lebih bersemangat untuk mengikuti senam karena bisa berinteraksi dengan teman-temanya dibandingkan hanya di rumah, mengingat bahwa 
pada usia ini seseorang masih memiliki kebutuhan interaksi sosial yang masih tergolong tinggi.

Menua adalah proses alami yang dihadapi manusia. Dalam tahap ini, pada diri manusia secara alami terjadi penurunan atau perubahan dalam hal biologis, psikologi serta sosial ekonomi yang saling beristeraksi satu sama lain. Keadaan itu cenderung berpotensi menimbulkan masalah kesehatan secara umum maupun kesehatan jiwa secara khusus pada individu lanjut usia (Affandi, 2009).

Faktor fisik merupakan faktor yang berhubungan dengan kondisi seseorang, meliputi keadaan atau kondisi kesehatan, umur dan sebagainya (Rusmi, 2008). Kondisi kesehatan seseorang bisa di ukur dari tingkat kesehatan rohani dan kebugaran jasmani yang sangat mempengaruhi seseorang dalam melakukan tindakan terutama kegiatan senam. Kusmaedi (2008) mengungkapkan, kebugaran jasmani adalah kemampuan tubuh seseorang untuk melakukan tugas dan pekerjaan sehari-hari tanpa menimbulkan kelelahan yang berarti, sehingga tubuh masih memiliki simpanan tenaga untuk mengatasi beban tambahan. Motivasi yang dipengaruhi oleh kondisi fisik seseorang berasal dari dalam diri individu yang mendorong untuk bertindak dalam rangka memenuhi kebutuhan fisik seperti kebutuhan jasmani, raga, materi, benda atau berkaitan dengan alam.

Berdasarkan hasil penelitian didapatkan bahwa terdapat pengaruh kondisi fisik terhadap keikutsertaan senam lansia di Wilayah Kerja Puskesmas Titue.Kondisi fisik yang sehat dan bugar akan membuat lansia lebih bersemangat untuk mengikuti senam, jika kondisi lansia tidak sehat membuat mereka enggan mengikuti senam lansia. Kondisi fisik juga sangat mendukung keaktifan lansia dalam beraktifitas. Tubuh yang tidak sehat membuat lansia lebih banyak beristirahat dan engggan untuk aktif dalam berbagai kegiatan karena kondisi tubuh yang lemah dan menahan rasa sakit akibat penyakit yang mereka derita.

Hasil penelitian ini sesuia dengan penelitian yang dilakukan oleh Jasmanto (2011) yang menyatakan bahwa kemampuan lansia dalam melakukan aktivitas senam lansia dipengaruhi oleh kondisi kesehatan yang baik. Sulastri (2006) menyatakan bahwa semakin buruk kondisi kesehatan seseorang maka akan semakin menurunkan minat untuk melakukan aktivitas fisik. Lansia dengan kondisi fisik yang baik akan memiliki motivasi lebih besar untuk mengikuti senam lansia dibandingkan dengan lansia yang memiliki kondisi fisik yang kurang baik. Hal ini dipengaruhi oleh kelemahan otot pada lansia dan berbagai keadaan kesehatan lainnya yang kurang baik sehingga membatasi lansia untuk melakukan aktivitas terutama gerakan senam.

Motivasi merupakan suatu pendorong yang menyebabkan suatu perubahan perilau. Motivasi lansia dalam mengikuti senam lansia dapat diperoleh dari berbagai hal antara lain motivasi keluarga, motivasi teman maupun motivasi dari petugas puskesmas. Berdasarkan hasil penelitian motivasi yang paling banyak membuat lansia berkeinginan untuk ikut serta dalam senam adalah motivasi teman. Menurut Maslow yang dikutip oleh Ngalim Purwanto bahwa perteman merupakan kebutuhan sosial (social needs), yang meliputi kebutuhan akan dicintai, diperhitungkan sebagai pribadi, rasa setia kawan, hal ini juga terjadi pada lansia dimana lansia mengikuti senam untuk kebutuhan social seperti mengobrol, saling bertukar informasi dan pengalaman maupun dan bercanda tawa.

Hasil penellitian menunjukkan motivasi merupakan salah satu faktor yag mempengaruhi keikutsertaan keikutsertaan senam lansia di Wilayah Kerja Puskesmas Titue. Semakin tinggi motivasi yang diberikan maka semakin tinggi pula keinginan lansia untuk ikut serta dalam senam lansia.

Hasil penelitian ini sejalan penelitian Suseno (2012) menunjukan bahwa pengetahuan, dukungan keluarga, motivasi dan keluhan fisik mempengaruhi keaktifan lansia mengikuti kegiatan Posyandu Lansia di Desa Kauman Kecamatan Polanharjo Kabupaten Klaten. Penelitian ini sejalan dengan hasil penelitian Novarina (2012) di Mendungan Desa Pabelan Kartasura menyatakan semakin tinggi tingkat dukungan keluarga maka semakin tinggi tingkat keaktifan lansia mengikuti senam. 
Tingkah laku seseorang pada hakikatnya ditentukan oleh suatu kebutuhan untuk mencapai suatu tujuan yaitu dengan adanya motivasi dalam diri seseorang untuk mencapai tujuan yang diinginkan. motivasi mengandung makna sebagai kekuatan yang menyebabkan seseorang terdorong untuk melakukan aktivitas tertentu dalam rangka memenuhi kebutuhan. Makin kuat dorongan tersebut maka makin optimal pula sesuatu yang dituju itu dapat dicapai

Motivasi berdasarkan faktor lingkungan ini tergantung dimana tempat seseorang berada dengan berbagai kegiatan yang dilakukan secara berulangulang, dirangsang, diawali, dan kemudian diarahkan. Perilaku atau aktivitas yang ada pada setiap individu tidak timbul dengan sendirinya tetapi sebagai akibat dari stimulus atau rangsangan dari luar, dan motivasi yang menstimulus seseorang paling besar biasanya adalah dari faktor lingkungan seperti jarak tempat tinggal terhadap tempat kegiatan senam lansia maupun pengaruh ajakan petugas kesehatan, teman dan dukungan keluarga

\section{KESIMPULAN}

Berdasarkan penelitian didapatkan kesimpulan bahwa terdapat pengaruh umur $(p=0,007)$, fisik $(p=0,000)$ dan motivasi $(p=0,019)$ terhadap keikutsertaan senam lansia di Wilayah Kerja Puskesmas Titue. Faktor umur, kondisi fisik dan motivasi memiliki pengaruh sebesar 30,7\% terhadap keikutsertaan senam lansia di Wilayah Kerja Puskesmas Titue dan faktor yang paling dominan dalam mempengaruhi keikutsertaan snam lansia adalah kondisi fisik. Diharapkan kepada Puskesmas Titeue diharapkan dapat lebih mengoptimalkan pelayanan kesehatan lansia terutama senam lansia dengan memberikan motivasi-motivasi yang melibatkan teman sebaya lansia dan diharapakan kepada lansia untuk menjaga kondisi fisknya dan dapat mengikuti senam lansialolaan data dan informasi di Puskesmas (52,4\%).

\section{DAFTAR PUSTAKA}

Affandi, Mochamad. (2009). Faktor-Faktor Yang Mempengaruhi Penduduk Lanjut Usia
Memilih Untuk Bekerja. Journal of Indonesian Applied Economic. Vol.3 No.2 Oktober 2009.

Agustina. (2010). Faktor-Faktor Yang Berhubungan Dengan Praktik Senam Lansia Di Panti Sosial Tuna Werda (PSTW Budi Mulia Oi Cipayung Jakarta Timur. Skripsi: Program Studi Ilmu Keparwatan UIN Syarif Hidayatullah

Budiharjo, dkk. (2009). Pengaruh senam aerobik low impact intensitas sedang terhadap kelenturan badan pada wanita lanjut usia tidak terlatih. Yogyakarta: Fakultas Kedokteran Universitas Gajah Mada

Dhenok, Dwi C. (2008). Pengetahuan lansia tentang latihan fisik di Posyandu lansia Rw2 Kelurahan Kesatrian Malang. Diakses dari http://www.poltekkessoepraoen.ac.id/

Ekasari, M.F (2008) Keperawatan Komunitas. Jakarta : Trans-Infomedia

Jasmanto. (2011). Hubungan antara olahraga senam dengan penurunan tekanan darah pada lansia penderita hipertensi di Panti Wredha Wening Wardoyo Ungaran. Telogorejo Skripsi. Tidak diterbitkan. STIKES Semarang

Kusmaedi, N (2008). Olahraga Lansia. Bandung : CV Bintang Warli Artika

Martono, H. Hadi., \& Pranarka, Kris. (2009). Geriatri ilmu kesehatan usia lanjut. Edisi 4. Jakarta: Balai penerbit FKUI

Mamik, R. 2013. Hubungan antara Pengetahuan dengan Keaktifan Lansia Datang Ke Posyandu Lansia di Dusun Kudu Desa Kudu BAnjar Kecamatan Kudu Kabupaten Jombang Tahun 2013. Jurnal: Stikes Pemerintah Jombang

Moniaga, V. 2013. Pengaruh Senam Bugar Lansia terhadap Tekana Darah Penderita Hipertensi di BPLU Senja Cerah Paniki Bawah. Jurnal: eBiomedik Vil 1 Nomor 2 Hlm 785-789

Ninggrum. (2008). Faktor-Faktor Yang Mempengaruhi Motivasi Lansia Mengikuti Senam Lansia Di Wilayah KerJa Puskesmas Banyudono.. Jakarta Timur

Novariana. (2012). Hubungan Dukungan Keluarga tentang Senam Lansia dengan Keaktifan Mengikuti Senam di Posyandu "Peduli Insani" di Mendungan Desa Pabelan Kartasura. Skripsi. Falkultas Ilmu Kesehatan Universitas Muhamadyah Surakarta.

Pidie. (2016). Profil Kabupaten Pidie diakses dari http://www.pidiekab.go.id 
Pudjiastuti, Dkk. (2013). Fisioterapi Pada Lansia. Jakarta: EGC

Sharkey, B.J. (2013). Kebugaran dan kesehatan. Jakarta: PT Raja Grafindo Persada

Sulastri. (2006). Faktor-faktor yang mempengaruhi keikutsertaan lansia pada kegiatan senam lansia di wilayah kerJa puskesmas Deli Serdang. Medan : Universitas Sumatra Utara Medan

Suseno. 2012. Factor-fakor yang mempengaruhi Keaktifan Lansia dalam mengikuti Kegiatan
Posyandu Lansia di Desa Kauman kecamatan Polanharjo Kabupaten Klaten

Widyastuti, V, W. (2013). Hubungan Tingkat Pengetahuan Tentang Senam Lansia Dengan Keaktifan Mengikuti Senam Lansia Di Unit Rehabilitasi Sosial, Wening Wardoyo Ungaran. Skripsi STIKes Telogerojo Semarang.

WHO. (2010). Definition of an older or elderly person Diakses dari http://www.who.int/healthinfo/survey/agei ngdefnolder/en/ 